Original article

\title{
Ring shake in chestnut: Anatomical description, extent and frequency of failures
}

\author{
Patrick FONTI ${ }^{\mathrm{a} *}$, Nicola MACCHIONI ${ }^{\mathrm{b}}$ \\ ${ }^{a}$ WSL Swiss Federal Research Institute, Sottostazione Sud delle Alpi, via Belsoggiorno 22, Casella postale 57, 6504 Bellinzona, Switzerland \\ b Istituto per la Valorizzazione del Legno e delle Specie Arboree, Consiglio nazionale delle ricerche, via A. Barazzuoli 23, 50136 Firenze, Italy
}

(Received 26 March 2002; accepted 21 November 2002)

\begin{abstract}
Ring shake is a wood defect that occurs very frequently in sweet chestnut (Castanea sativa Mill.). By examining this particular kind of wood failure it is apparent that, at an anatomical level, separations occurring in the wood tissue show different features. In order to collect further information to help in understanding the causes that lead to the development of ring shake, a microscopic description and a quantification of these different ring shake typologies has been performed on 45 chestnut wood discs. Results showed that among the various shake types encountered, the crack-form, i.e. the failure that develops across the earlywood cell walls, is largely the most frequent and is principally found in fresh felled wood. Detailed observations reinforce the belief that the set off mechanism leading to crack-failure is related to the combined interaction of the structural weakness of chestnut wood with growth stresses developed in the stem.
\end{abstract}

Castanea sativa / ring shake / fracture anatomy

Résumé - La roulure du châtaignier : description anatomique, ampleur et fréquences des séparations. La roulure est un défaut du bois qui se produit très fréquemment dans le châtaignier (Castanea sativa Mill.). En examinant ce genre particulier de rupture il est visible au niveau anatomique que les séparations qui se produisent dans le bois montrent des faciès de rupture différents. Afin de disposer d'informations nécessaires à la compréhension des causes qui mènent au développement de la roulure, une description microscopique et une quantification des différentes typologies de roulure ont été effectuées sur 45 disques de châtaignier. Les résultats ont montré que parmi les divers types de roulure observés, la forme de rupture "crack", c'est-à-dire la séparation qui se développe à travers les parois cellulaires des vaisseaux du bois initial, est la plus fréquente et se présente principalement dans le bois fraîchement abattu. Les observations microscopiques détaillées renforcent la conviction que le mécanisme conduisant à cette forme de rupture est lié à la faiblesse structurale du bois de châtaignier combinée avec les contraintes de croissance développées dans la tige.

Castanea sativa / roulure / anatomie de fracture

\section{INTRODUCTION}

Looking at the stem cross-section of different wood species we can observe the presence of circular failures running parallel to the growth ring which strongly downgrade otherwise valuable timber. This particular kind of tangential shake is commonly called "ring shake" and is defined as "a lengthwise separation of wood which occurs between and parallel to the growth layers". The development of such fractures depends on the balance between stresses and strength: when the first one exceeds the second then the shake opens. The literature analysis reveals many different opinions as to the causes of shake, but all either refer to an increase of stresses due to the effect of wind [10, $26]$, frost $[8,10]$, sudden changes in diameter growth rates [12], relieving of growth stresses [1, 13]; or to a weakened wood strength caused by cambial damage $[11,16,18,21,22$, 25], environmental stress [25] or by a lack of substances in the soil and the tree [14]. Several studies based on the description of the anatomical features of shake surfaces permitted further discussion about the possible causes of ring shake and about when the separation have likely occurred [16, 17, 25].

Castanea sativa is an hardwood specie that is very often affected by ring shake [4]. In this specie different types of ring shake separations have been observed. Chanson et al. [3], considering the origins of the split, distinguished between "traumatic" and "healthy" ring shake. The first type is always related to visible anomalies in the wood tissue, whereas for the second one the splitting appears to be unrelated to any recognizable anatomical perturbation. Moreover, among these two types, three additional anatomical fracture surfaces have also been

\footnotetext{
* Corresponding author: patrick.fonti@wsl.ch
} 


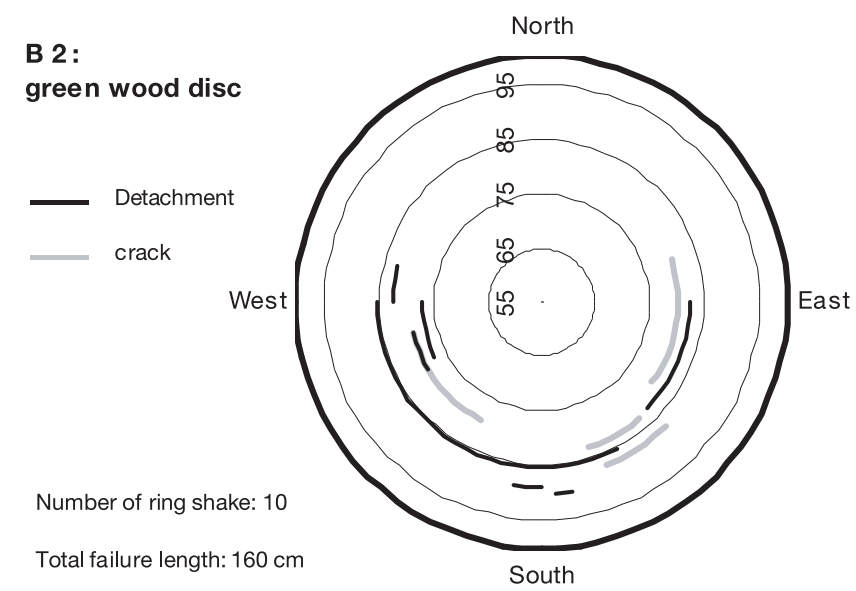

Figure 1. Schematic location of shakes on disc. The year of the annual ring is represented by thin lines, one each 10 rings starting from year 1955 .

observed: the "overlay", that corresponds to a new layer superposed on traumatic cells; the "detachment", that appears as a separation along the compound middle lamella between cells but leaving intact the cell walls; and the "crack", where the failure develops across the earlywood vessel cell walls [7]. While it is clear that the overlay originates from cambium damage, the reasons for the development of the other two features are rather unclear, even if all the authors dealing with this specie agree on the mechanical failure hypothesis. It is however possible that the cracks and the detachment features have different origins or developmental processes that lead to dissimilar anatomical failure characteristics. Thus these aspects have to be taken into account when inquiring into the possible causes of ring shake. To this date, however, few descriptive studies on the anatomical characteristics of the ring shake zones in chestnut have been carried out $[3,20]$.

The objective of this research is therefore to perform a detailed description of the different anatomical ring shake fractures. In particular we aim to furnish a report on wood surface separations from the anatomical point of view, as well as a quantification of their extent and frequency. We hope therefore, through this new knowledge, to contribute to the discussion of the possible causes leading to ring shake in chestnut wood.

\section{MATERIALS AND METHODS}

The wood material used for this study originates from 2 mature coppice stands situated in Bedano and Bedigliora, in the Southern part of the Swiss Alps. Both stands have been growth unmanaged since the last coppicing which occurred in the 1940s. From each stand at least 20 dominant shoots were selected from the overstory trees, 24 from the stand in Bedano and 21 from that of Bedigliora. Immediately after the felling, $5 \mathrm{~cm}$ thick wood discs were gathered from the stem base $(50 \mathrm{~cm}$ above ground level) of each selected shoot. The collected discs were then polished with a 150 grit sand paper in order to obtain a clean cross-section allowing an easy identification and characterization of the anatomical details of the different ring shake typologies. The observations were performed on each wood disc twice: once on the fresh collected green wood discs, i.e. within 3 days after the tree-felling (discs were stored in a controlled environment at $20{ }^{\circ} \mathrm{C}$ and $90 \%$ relative humidity), and then repeated on the same wood discs after being dried in fresh air under shelter for about 1 year.

The characterization and quantification of ring shake was performed on the disc cross-sections (Fig. 1). All visible tangential failures longer than $1 \mathrm{~cm}$ were taken into account. Each single ring shake was then characterized by its position on the disc (distance from the pith, orientation and solar year of the annual ring affected by the split), length and type of wood failure (overlay, detachment or crack).

Using a Scanning Electron Microscope (SEM Philips XL 20), a detailed micro-anatomical description of the surfaces of the different failure typologies was made on the tangential and/or transversal plane of few samples (two from each ring shake typology) from the collected wood material. After boiling in water microscopic samples were cut on the transversal and radial planes, without altering the tangential surface failure caused by ring shake.

\section{OBSERVATIONS}

\subsection{Anatomical features of shake zone}

\subsubsection{Overlay}

The overlay-form is not exactly a fracture because a connection between the two separated layers never existed. In fact, as a cicatrisation caused by cambial damage, the tree from the near non-traumatic tissue just superposed, without any physical connection, a new annual increment layer onto the traumatic one. Moreover, as a consequence of microorganisms that penetrated the wound, the nearby zone often displays discoloration and decay. The overlay-form is therefore easy to recognise thanks to the characteristic overgrown callous tissue and the discoloration in the nearby area (Fig. 2). The injury causing the cicatrisation is a sudden event that acts on the last formed tissue: its aspect is then random and its anatomical description cannot be generalised.

\subsubsection{Detachment}

The fractures of the detachment typology are mainly located along the boundary between two annual rings, even if from time to time a small excursion into the earlywood area is noted, giving therefore the impression of a "crack" failure (Fig. 3). The failed surface is mainly smooth because the mechanism of tissue failure is a cell-to-cell debonding from the compound middle lamella rather than a cell wall failure. As Figure 3 shows the failed surface does not exhibit any sign of cell cracking, even for the parenchyma ray cells, whose walls at the end of the annual growth ring are still intact. Here the ray cells are broken flush with the surface. A special case of detachment that also rarely occurs is discoloured detachment, which is a disconnection that occurs due to a weak bond between cells resulting from trauma and decay. Therefore, some discoloration in proximity of the detachment is clearly visible.

\subsubsection{Crack}

From the anatomical point of view the crack-typology is essentially a cell wall failure that mainly develops in the tangential plane crossing the first or second row of earlywood 
Table I. Summary of the ring shake failure length observed in green and dried wood discs differentiating between the different failure typologies.

\begin{tabular}{|c|c|c|c|c|c|c|c|c|c|c|c|c|c|}
\hline \multicolumn{2}{|c|}{ Ring shake failure length } & \multicolumn{4}{|c|}{ Green wood discs } & \multicolumn{4}{|c|}{ Increment due to drying } & \multicolumn{4}{|c|}{ Dried wood discs } \\
\hline & & $\mathrm{C}$ & $\mathrm{D}$ & $\mathrm{O}$ & $\Sigma$ & $\mathrm{C}$ & $\mathrm{D}$ & $\mathrm{O}$ & $\Sigma$ & $\mathrm{C}$ & $\mathrm{D}$ & $\mathrm{O}$ & $\Sigma$ \\
\hline \multirow[t]{2}{*}{ Bedigliora } & $\mathrm{cm}$ & 1205 & 116 & 21 & 1342 & 451 & 252 & - & 703 & 1655 & 369 & 21 & 2045 \\
\hline & $\%$ & 90 & 9 & 1 & 100 & 64 & 36 & 0 & 100 & 81 & 18 & 1 & 100 \\
\hline \multirow[t]{2}{*}{ Brione } & $\mathrm{cm}$ & 1650 & 229 & 39 & 1918 & 583 & 81 & - & 655 & 2233 & 310 & 39 & 2583 \\
\hline & $\%$ & 86 & 12 & 2 & 100 & 88 & 12 & 0 & 100 & 84 & 15 & 1 & 100 \\
\hline \multirow[t]{2}{*}{ Total } & $\mathrm{cm}$ & 2855 & 345 & 60 & 3260 & 1034 & 333 & - & 1368 & 3889 & 679 & 60 & 4628 \\
\hline & $\%$ & 88 & 11 & 2 & 100 & 76 & 24 & 0 & 100 & 84 & 15 & 1 & 100 \\
\hline
\end{tabular}

$\mathrm{C}=$ Crack, $\mathrm{D}=$ Detachment, $\mathrm{O}=$ Overlay, $\Sigma=$ Sum of all typologies.

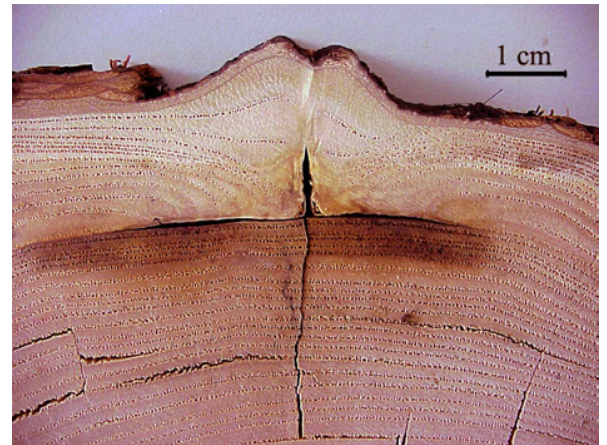

Figure 2. Overlay-form: the ring shake is due to the physical separation of the injured tissue and the cicatrisation tissue.

vessels (Fig. 4). The rough failed surface (tangential section) is characterised by radial parenchyma cells (uniseriate rays) that still denote the pulling effect that occurred during the opening of the failure, as well as by broken vessels and disrupted fibres.

\subsection{Extent and frequency of shakes}

From the 45 selected wood discs, only few were ring shake free. In fact only $8(18 \%)$ green discs and $4(9 \%)$ dried discs showed no ring shake. Few other discs, 6 (13\%) green and 7 (16\%) dried, were only slightly affected by ring shake, i.e. the total ring shake failure length was less than $20 \mathrm{~cm}$. This means that $69 \%$ of the green and $75 \%$ of the dried discs displayed more than $20 \mathrm{~cm}$ of failure length. Among these, there were two extremely shaken discs that exhibited more than $3 \mathrm{~m}$ of ring shake failure length.

As shown in Table I, the crack-form is largely the most frequent failure typology, representing $88 \%$ (90\% for the stand of Bedigliora and $86 \%$ for Brione) of all the ring shakes observed in green wood, while in the dried wood this proportion slightly diminishes to $84 \%$ ( $81 \%$ for Bedigliora and $86 \%$ for Brione). The other two failure typologies are instead less recurrent with $11 \%$ (green) and 15\% (dried) being of the detachment typology and about $2 \%$ of the overlay-form, which of course did not increase with the drying.

The green wood ring shakes represent $70 \%(3260 \mathrm{~cm})$ of the entire observed ring shakes, while a further $30 \%(1368 \mathrm{~cm})$ developed during the drying process (Tab. I). These last formed fractures have been mainly surveyed on discs that were already affected by the defect (Fig. 5). The more the green wood is affected by ring shakes, the more ring shakes, in particular of the crack typology, tend to develop during the drying-process, confirming previous observations performed by Fonti et al. [6].

\subsection{Shake distribution}

The analysis of the ring shake distribution according to the year of the annual ring, differentiated between the two stands, shows that both the detachment and crack-form are not strictly related to specific annual increments (Fig. 6). Looking however at each single wood disc we often observed that failures, in particular the crack-form, follow one ring for some distance but then rather abruptly cross radially into a neighboring ring and then further proceed into the earlywood tissue. This "jumping" from ring to ring could also occur several times in the same ring shake failure, giving the failure a zigzag shape.

\section{DISCUSSION AND CONCLUSION}

\subsection{Origin}

Several authors mainly associated ring shake formation with injuries $[11,16,18,21,22,25]$. In this descriptive study on chestnut wood, ring shakes originating from an evident traumatic event (overlay) represented only $1 \%$ of all the failure lengths observed.

The detachment-shake, i.e. failure arising in the compound middle lamella layer, is somewhat more frequent (15\%). In the literature this kind of fracture was often reported as being located in the latewood area and associated with green wood ring shake $[11,15,17]$. In our study however the separation always appears at the ring boundary and can be found both in green wood and as a result of the drying process. In her study, Saya [20], possibly describing such a fracture, has observed a compound middle lamella lignin deficiency. This could be indicative of external events that influenced the bonding-quality between annual growth layers. Genetics, lack of substances in the soil [14] or damage to the tree may be reasons for the poor bonding-quality. In fact, if the shake is observed at a point far from the wound, the association of the wound with the shake will not be directly recognised [22]. The rarely observed discoloured detachment-form supports this suggestion. And finally, as there is no apparent relationship between specific annual 

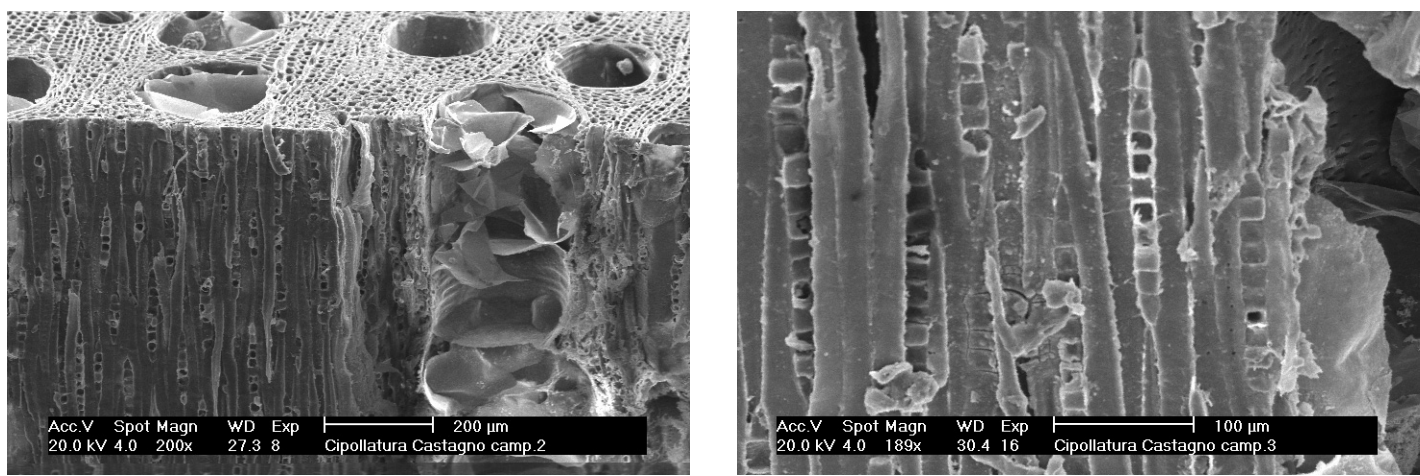

Figure 3. Detachment-form: the failed surface is generally smooth even if a small excursion into the earlywood area sometimes occurs (on the left image); the right image shows the aspect of the radial parenchyma cells which are occluded between annual ring membranes.
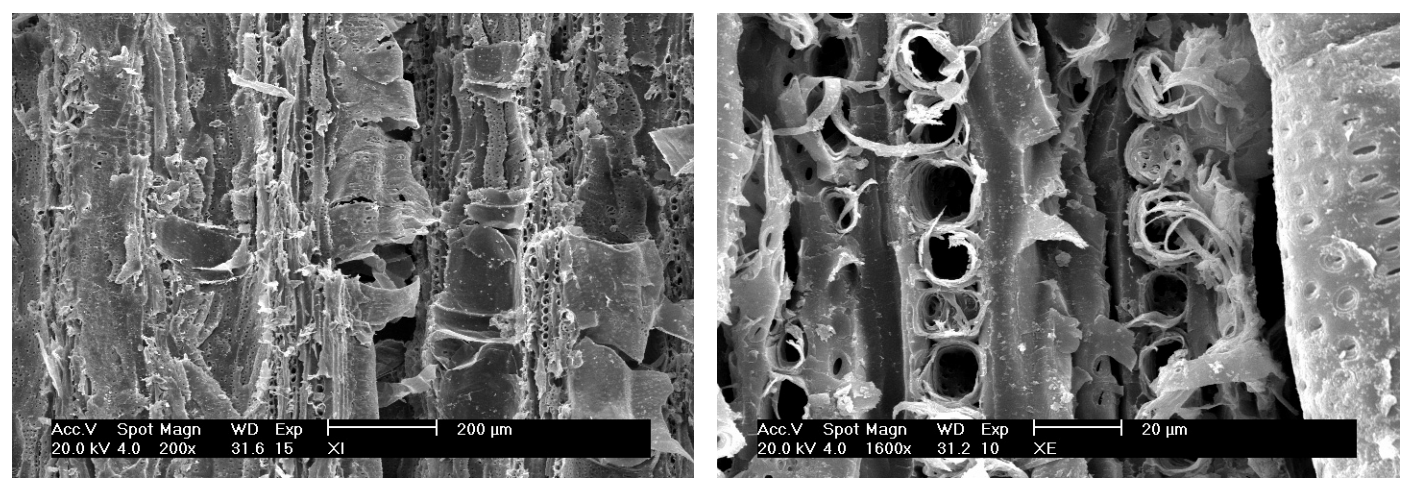

Figure 4. Crack-form: the rough surface (on the left) is due to the fracture pattern running between the earlywood vessels; the aspect of the ray tissue (on the right) is similar to that of "pulled" cells.

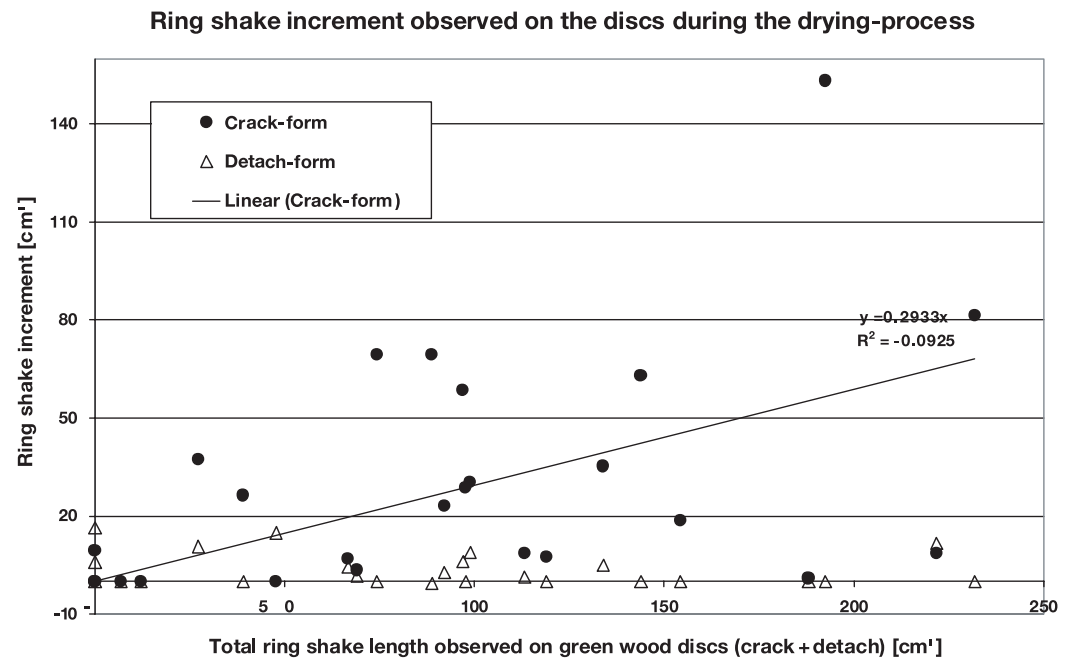

Figure 5. Ring shake increment observed on each single disc during the drying process.

increments and the occurrence of this kind of shake, the opening may rather be associated with single tree events. However, cambial damage as a cause of ring shake must be taken as a special case, and does not account for the majority of shake.
The most frequent feature observed is indeed the crack-form, i.e. ruptures in which the cell walls are usually broken, which represented $84 \%$ of the total ring shake failures surveyed. In chestnut this separation principally develops in the earlywood area 


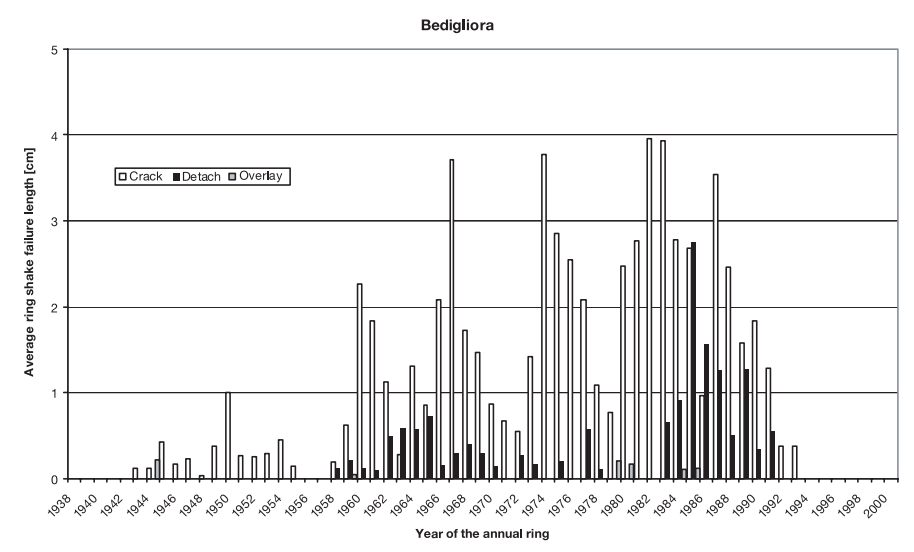

Figure 6. Ring shake distribution.

proceeding across the large earlywood vessels. The fracturing that occurs appears to involve a minimal quantity of wood.

With no noticeable abnormal wood tissue in the shake surface, this shake-form has therefore a merely mechanical origin, which is regulated by the interaction between the strengths and stresses in the wood.

The ring porous wood structure and the small uniseriate rays in chestnut confer a privileged (weak) plane for the opening and propagation of this kind of tangential failure. The earlywood zone is an area of structural weakness and therefore especially vulnerable to stresses which could cause separation. The timing in which fractures occur, which is generally before timber processing, and the often observed ring-to-ring jumping pattern of shakes lets us presume that the set off mechanism leading to this failure has to be related to stresses acting on the standing tree or on the fresh felled stem.

These observations highlight therefore former hypotheses that the mechanism leading to crack separation is related to the interaction between wood fragility and the release of growth stresses [1, 2, 9, 13, 24]. The increase of new ring shake during the drying process, limited to already severely shaken green wood discs, could therefore indicate that each single disc has its own susceptibility to ring shake, which continues on into the drying process. This may lead back to an intrinsic fragility or to an amount of unrelieved stress specific to the considered individual.

\subsection{Hypothesis on the mode of loading responsible for the different ring shake forms}

Based on the performed morphological description of the surface failures a preliminary supposition about the responsible mode of fracture can be formulated. As opposed to traumatic ring shake, healthy ring shake has a mechanical origin. However from simple fracture morphological observation it is difficult to advance a hypothesis on the typologies of stresses (mode I, II or III) imposed on the transversal/radial wood plane, even if some indications suggest allocating the crack typology to mode I and the detachment typology to mode II. No studies of ring shake in chestnut wood have compared the aspect of the ring shake failures to those of the typologies of
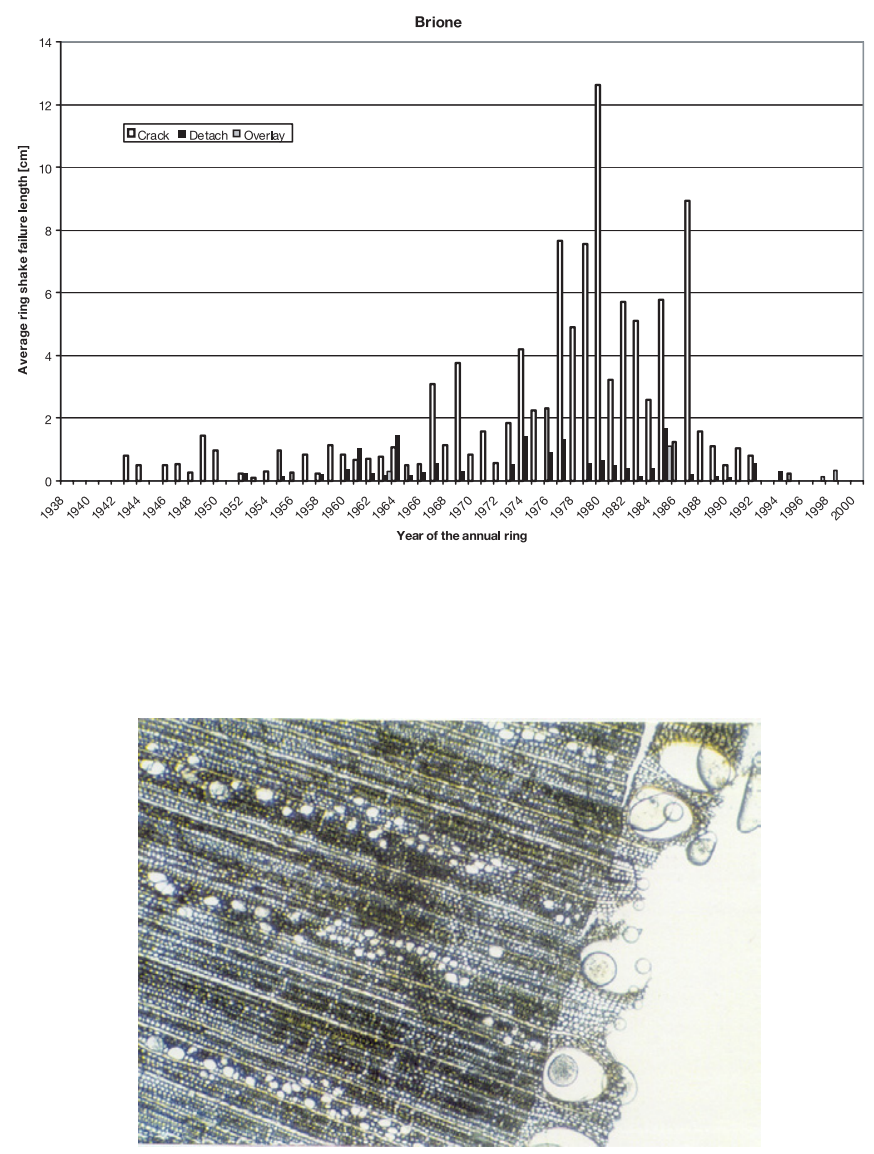

Figure 7. Facet of chestnut wood broken by radial bending test: the fracture line runs along the earlywood vessels as in the "crack" form (image Pozzi [19]).

stresses imposed on the transversal-radial plane of wood. But modelling the mode I and II crack propagation on spruce (Picea abies Karst.) wood, Tan et al. [23] analysed by means of SEM the longitudinal tangential surface fractures. Taking into account the differences between spruce and chestnut wood, we can observe that the mode I produces fracture surfaces located within the earlywood, breaking the cell walls, resulting in an aspect similar to what we have called "crack". In spruce wood the mode II produces a large number of warped broken tracheids, while the behaviour of chestnut fibres is different and the mode I fracture causes the detachment of adjacent fibres along the compound middle lamella.

An unpublished thesis from Pozzi [19] attempted an anatomical comparison between the crack- and detach-failure ring shake typologies and those of samples artificially broken in the tangential plane through radial bending and radial shear. This study revealed that samples broken through radial bending performed on green wood (mode I) are similar to the "crack-form" with the fissure breaking the thin and weak cell walls of the first and second rows of earlywood vessels (Fig. 7), while the shear fractures in dried wood samples are similar to the "detachment-form" (Fig. 8). It is therefore reasonable to suppose that each typology of ring shake has its 


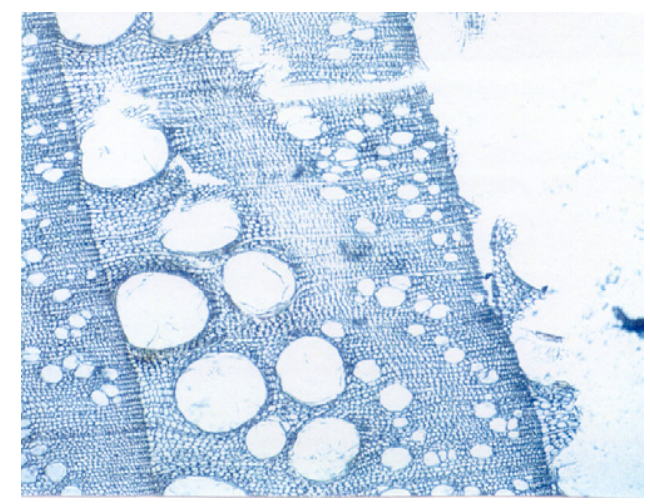

Figure 8. Facet of shear fracture on chestnut wood: the fracture is similar to the detachment-form (image Pozzi [19]).

own mechanism. Further investigation may help in establishing which fracture mechanism is responsible for which kind of failure.

The anatomical observation suggests therefore that the development of the crack typology seems to be linked to a radial stress that breaks the earlywood vessels. These observations reinforce the hypothesis that ring shake develops frequently in chestnut wood, because of the structural weakness that predisposes this species to this kind of fracture, which is mainly regulated by the relieving of growth stresses during the tree-felling. Therefore further studies on this topic, with the aim of reducing the risk of ring shake, must consider in particular the development of the crack-form ring shakes that appear before or immediately after the tree-felling. The few detachment failures seem instead to be linked to the rolling shear stresses caused in the tangential plane by the drying process along the abrupt transition between latewood and earlywood. At this location there is an elevated difference in shrinkage between the porous zone and the preceding latewood [5], especially in the more fragile wood of already shaken trees.

Acknowledgements: The authors want to thank Simona Lazzeri, technician at the IVALSA-CNR, for preparing the samples for SEM analysis and for the relevant images.

\section{REFERENCES}

[1] Archer R., Growth stresses and strain in trees, Springer Verlag Berlin, 1986.

[2] Boyd J.D., Tree growth stresses. II. The development of shakes and other visual failures in timber, Aust. Jor. Appl. Sci. 1 (1950) 296-312.

[3] Chanson B., Leban J.-M., Thibaut B., La Roulure du châtaignier, For. Méditerr. 11/1 (1989) 15-32.
[4] Ferrand J.-C., La roulure du châtaignier (Castanea sativa Mill.). Note préliminaire, Seichamps (France CNRF), 1980, 17 p.

[5] Fioravanti M., Caratterizzazione del legno giovanile di castagno (Castanea sativa Mill.): studi su anatomia, densitometria e variazioni dimensionali, Dottorato, Università degli studi di Firenze, 1992, p. 75 .

[6] Fonti P., Giudici F., Kucera L.J., Ott E. Pöhler E., Studio sulla cipollatura in un ceduo castanile, Atti del convegno nazionale sul castagno, Cison di Valmarino (Treviso), 1998, pp. 293-302.

[7] Fonti P., Macchioni N., Thibaut B., Ring shake in chestnut (Castanea sativa Mill.): state of the art, Ann. For. Sci. 59 (2002) 129-140.

[8] Fostier G., Frost injuries in Oak, For. Abstr. 14 (1953).

[9] Fournier M., Chanson B., Thibaut B., Guitard D., Mécanique de l'arbre sur pied: modélisation d'une structure en croissance soumise à des chargements permanents et évolutifs. 1. Analyse des contraintes de support, Ann. Sci. For. 48 (1991) 513-525.

[10] Harrar E.S., Defects in hardwood veneer logs: their frequency and importance. US Forest service SE Forest experiment station 39, 1954.

[11] Kandeel S.A., McGinnes E.A.J., Ultrastructure of ring shake in scarlet oak (Quercus coccinea, Muench), Wood Sci. 2 (1970) 171-178.

[12] Koehler A., A new hypothesis as to the cause of shakes and rift cracks in green timber, J. For. 31 (1933) 551-556.

[13] Kübler H., Growth stresses in trees and related wood properties, For. Prod. Abstr. 10 (1987) 61-119.

[14] Lachaussée E., Note upon shake and forest crack of Quercus robur, For. Abstr. 15 (1953) 1598.

[15] McGinnes E.A.J., Extent of shake in black walnut, For. Prod. J. 18 (1968) 80-82

[16] McGinnes E.A.J., Phelps J.E., Ward J.C., Ultrastructure observations of Tangential shake formation in Hardwoods, Wood Sci. 6 (1974) 206-211.

[17] Meyer R.W., Lawrence L., Shake in coniferous wood: an anatomical study, For. Prod. J. 18 (1968) 51-56.

[18] Owen D.O., Wilcox W.W., The association between ring shake, wetwood and fir engraver beetle attack in white fir, Wood Fiber 14 (1982) 267-280.

[19] Pozzi F., Studio anatomico comparativo sulle modalità di frattura del legno di castagno (Castanea sativa Mill.): campioni affetti da cipollatura e campioni rotti meccanicamente, Tesi di Laurea, Università degli studi di Torino, 1996, p. 90.

[20] Saya I., Indagine sulla cipollatura del legno di castagno e di abete bianco, Contributi scientifico-pratici per una migliore conoscenza e utilizzazione del legno 6 (1962) 37-41.

[21] Shigo A.L., Ring shake associated with sapsucker injury, U.S. For. Serv. Res. Pap. NE-8, 1963.

[22] Shigo A.L., Ring and ray shakes associated with wounds in Trees, Holzforschung 26 (1972) 60-62.

[23] Tan D.M., Stanz-Tschegg S.E., Tschegg E.K., Models of wood fracture in Mode I and Mode II, Holz als Roh- und Werkstoff 53 (1995) 159-164.

[24] Thibaut B., Fournier M., Jullien D., Contraintes de croissance, recouvrance différée à l'étuvage et fissuration des grumes : cas du châtaignier, For. Méditerr. 16 (1995) 85-91.

[25] Wilkes J., Anatomy of zones of ring shake in Eucalyptus maculata, IAWA Bulletin n. s. 7 (1986) 3-11.

[26] Wilson B.F., A survey of the incidence of ring shake in eastern hemlock, Harvard Forest Papers 5, 1962. 